\title{
Environmental Risk Assessment of Industrial Enterprises on BRICS Countries Industry Materials
}

\author{
Cheng S. \\ Southern Federal University \\ Rostov-on-Don, Russia
}

\author{
Murzin A. \\ Southern Federal University \\ Rostov-on-Don, Russia \\ admurzin@sfedu.ru
}

\author{
Dubskaya O. \\ Southern Federal University \\ Rostov-on-Don, Russia
}

\begin{abstract}
This article starts with data related to the industrial development of the BRICS countries, and begins to pay attention to the corporate environmental risks of China, Russia and other BRICS countries. After analyzing the pros and cons of several risk assessment methods, it focuses on a simple and easy-to-operate environmental factor, factor evaluation method. This method has wide adaptability, does not require high mathematical skills of the operator, and does not require complex tools for initial statistics. Subsequently, for Chinese and Russian related companies, the author gave opinions and suggestions on avoiding and reducing environmental risks. Finally, it summarizes the role of corporate environmental risks in sustainable development.
\end{abstract}

Keywords-environmental risk, Chinese enterprises, Russian enterprises;risk assessment

\section{INTRODUCTION}

Risk is everywhere, but scholars have different perceptions and definitions of risk. In environmental risk assessment and management, risk is generally defined as a loss caused by a deviation between the actual situation and the expected situation (that is, the actual value and the expected value) of an event. It is characterized by the probability and The product of the consequences of harmful events [1-3]. Environmental risk refers to the actual or potential threats to the organism and the environment caused by the organization's business activities, such as emissions, waste, and resource depletion[4-5]. For enterprises, the environmental risks caused by their waste discharge mainly fall into the following categories: environmental risks caused by soil or land pollution; environmental risks caused by water pollution; environmental risks caused by air pollution; Environmental risks caused by damage to the health of residents around employees; environmental risks caused by the adverse effects of waste on the local ecosystem.
For industrial enterprises, the environmental risks caused by their waste discharge mainly fall into the following categories: environmental risks caused by soil or land pollution; environmental risks caused by water pollution; environmental risks caused by air pollution; Environmental risks caused by damage to the health of residents around employees by waste; environmental risks caused by the adverse effects of waste on the local ecosystem, etc

\section{RESEARCH METHODS AND MATERIALS}

The study is based on materials from the Chinese industry. The indicators of the dynamics of the ecological situation according to official statistics were used as empirical data. The depth of the statistical sample is determined by the available open data and is 6 years: 2001-2016. This period is characterized by intensive industrial production and exploitation of natural resources.

Indicators of heavy metals pollution, dynamics of production of steel, paper and paperboard, as the main technological materials of the industry, are used as the initial data for the analysis

Risk analysis is performed by categories: Air Pollution,Water pollution, Solid waste pollution, Sound pollution, Radiation pollution and Other pollution. The study uses methods of statistical analysis, tabular comparison, and classical quantitative risk assessment.

\section{RESULTS AND DISCUSSION}

Since 1978, China's industry has achieved tremendous development. From 1990 to 2003, the total industrial output value of the People's Republic of China grew at an average annual rate of $12.7 \%$, and in 2017 industrial output value accounted for $40.5 \%$ of China's gross national product (GDP) [6]. After China joined the WTO in 2001, various industrial 
indexes have steadily increased year by year along with exports. In particular, the export volume of various industrial manufactured products has increased year by year. The scale and number of Chinese industrial enterprises have also developed rapidly. A series of environmental problems have also arisen. Just take the discharge of heavy metal pollutants in industrial wastewater as an example (Tab. 1)

TABLE I. THE DISCHARGE OF HEAVY METAL POLLUTANTS FROM THE INDUSTRIAL WASTEWATER OF CHINESE INDUSTRIAL ENTERPRISES IN 2015 [7]

\begin{tabular}{|c|c|c|}
\hline Pollutants & $\begin{array}{c}\text { Total } \\
\text { emission } \\
\text { (unit: ton) }\end{array}$ & Main industries and proportions \\
\hline $\mathrm{Hg}$ & 0.98 & $\begin{array}{l}\text { Non-ferrous metal smelting and rolling } \\
\text { processing industry } 29.4 \% \text {, non-ferrous metal } \\
\text { mining and dressing industry } 24.2 \% \text {, } \\
\text { chemical raw material and chemical product } \\
\text { manufacturing } 23.0 \%\end{array}$ \\
\hline $\mathrm{Cd}$ & 15.5 & $\begin{array}{l}\text { Non-ferrous metal smelting and rolling } \\
\text { processing industry } 69.7 \% \text {, non-ferrous metal } \\
\text { mining and processing industry } 19.2 \% \text {, } \\
\text { ferrous metal smelting and rolling processing } \\
\text { industry } 2.6 \%\end{array}$ \\
\hline $\mathrm{Pb}$ & 77.9 & $\begin{array}{l}\text { Non-ferrous metal smelting and rolling } \\
\text { processing industry } 41.6 \% \text {, non-ferrous metal } \\
\text { mining and dressing industry } 39.4 \% \text {, } \\
\text { chemical raw material and chemical product } \\
\text { manufacturing industry } 6.2 \%\end{array}$ \\
\hline As & 111.6 & $\begin{array}{l}\text { Non-ferrous metal mining and dressing } \\
\text { industry } 38.0 \% \text {, chemical raw material and } \\
\text { chemical product manufacturing industry } \\
29.5 \% \text {, non-ferrous metal smelting and rolling } \\
\text { processing industry } 23.8 \%\end{array}$ \\
\hline $\mathrm{Cr} 6+$ & 23.5 & $\begin{array}{l}\text { Metal products industry } 67.6 \% \text {, ferrous metal } \\
\text { smelting and rolling processing industry } \\
10.8 \% \text {, leather, fur, feathers and their } \\
\text { products and footwear industry } 9.0 \%\end{array}$ \\
\hline Total Cr & 104.4 & $\begin{array}{l}\text { Leather, fur, feather products and footwear } \\
\text { industry } 49.8 \% \text {, metal product industry } \\
35.1 \% \text {, ferrous metal smelting and rolling } \\
\text { processing industry } 6.2 \%\end{array}$ \\
\hline
\end{tabular}

At present, China's industrial energy consumption accounts for more than $80 \%$ of the total energy consumption. Entering the 21st century, China's total industrial waste gas and wastewater emissions have grown rapidly. Among them, industrial waste gas emissions have increased from 138145 billion cubic meters at the beginning of the century to 69419 billion cubic meters in 2014, and the total industrial wastewater emissions have also increased from 41.52 billion tons to 71.62 billion tons [7]. At present, the pollution of industrial enterprises in China is still very serious. Based on the pollution problem of industrial enterprises, research on environmental risks is increasing.

According to the BRICS Statistical Yearbook, as the world's major emerging industrial countries, the consumption of energy and natural resources in the BRICS countries is increasing year by year. For other BRICS countries that are also emerging economies, the same problem exists. Such problems are particularly prominent in Russia, which is dominated by the energy industry. It is necessary to study the environmental risks of enterprises and avoid or reduce them in advance.

Production dynamics of steel, paper and paperboard, as the main technological materials of the industry, presented on Figures 1-2 [8].

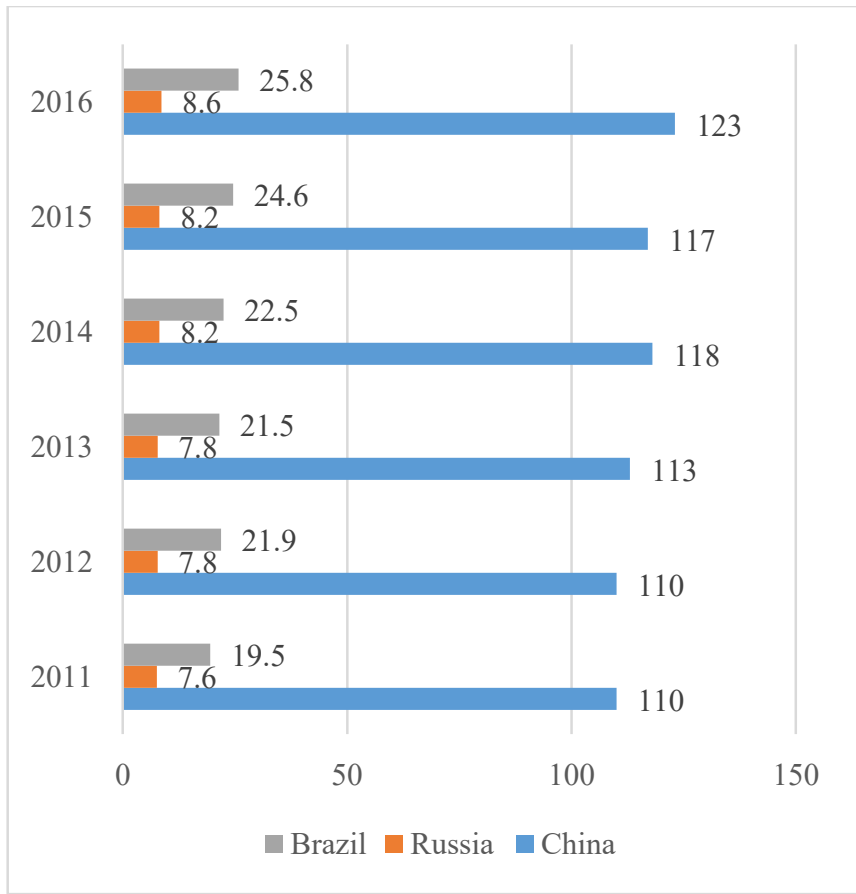

Fig. 1. Paper and paperboard Products of the BRICS countries over the years not include South Africa and India (unit: million tons)

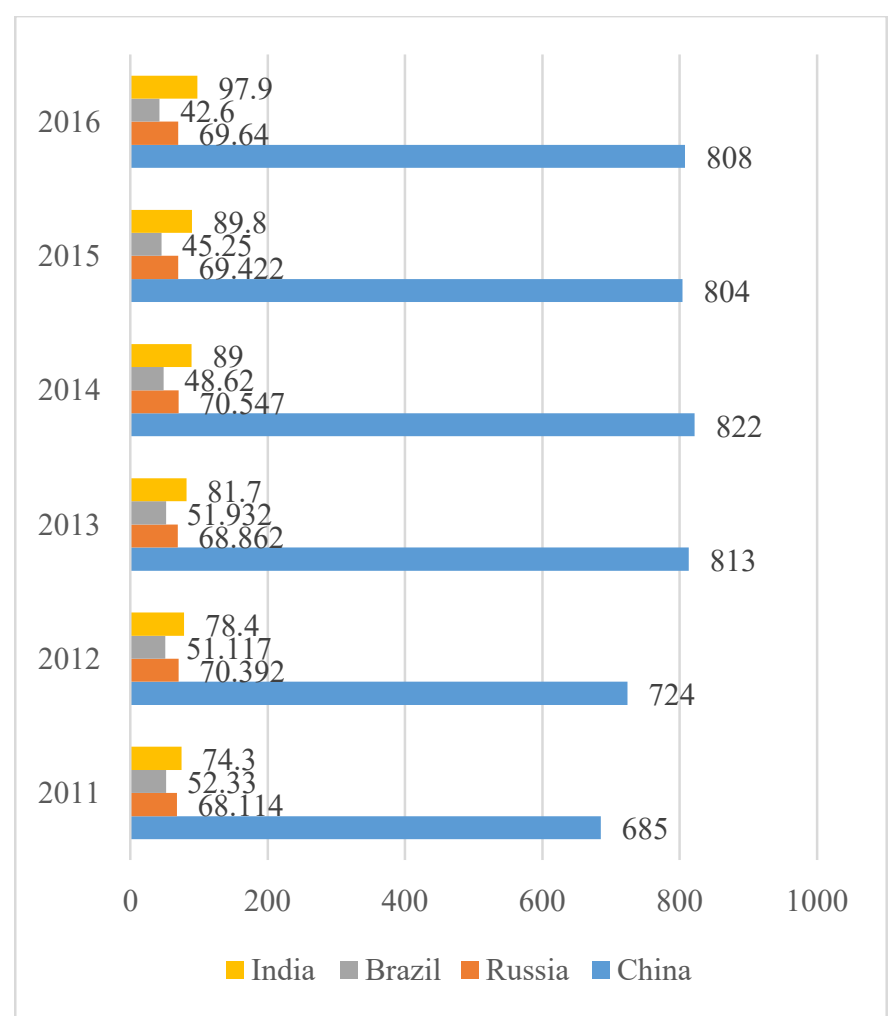

Fig. 2. Steel Products of the BRICS countries over the years not include South Africa(unit: million tons) [8]

The Ministry of Ecology and Environment of the People's Republic of China defined in government documents as: Environmental risks are "caused by natural causes or human activities, spread through environmental media, and can cause damage, damage or even destruction to human society and the natural environment. The probability and consequences of such 
unfortunate events. European and American scholars started early in the study of environmental risks, and most of them focused on risk and risk control. At present, the commonly used evaluation methods in China are: gray clustering method, analytic hierarchy process, fuzzy synthesis Evaluation, BP neural network. Gray clustering method is a gray system that can handle incomplete information. Through classification and identification of the attributes of the gray system, objective results can be obtained. The disadvantage is that there are many transportation projects and cumbersome steps. AHP can be used for multiple indicators The comprehensive evaluation and decision analysis of complex problems with multiple levels and multiple schemes can be used for both quantitative analysis and qualitative analysis. Disadvantages are large-scale problems with many factors and high quantitative requirements for decision-making problems, because of the method implementation process There is a scoring process, it is difficult to objectively evaluate the problem. The fuzzy comprehensive evaluation method is suitable for systems with multiple structural levels and multiple evaluation factors. It is simple and easy to operate. The disadvantage is that this method cannot be used if there is a correlation between the indicators. BP neural network It is a network model with a wide range of applicability . It has complex nonlinear processing capabilities. Due to the setting of the network structure and the problem of learning idle numbers, it has strong generalization ability and easy control of errors. But the disadvantage of BP neural network is evaluation The model has limitations. The construction of evaluation index results requires a lot of data, and the convergence speed is slow and time-consuming due to the immutable learning rate. In addition, the number of hidden layer nodes is not easy to determine. Too few or too many nodes are not good, training It is easy to reach the local minimum without obtaining the best advantage, which leads to the unstable structure of the neural network and is not simple enough [9]. The above complex calculation methods are not universal. This article introduces a quantitative analysis of environmental multi-factors Evaluation method.

The final result of risk evaluation is to determine the risk. Based on the known why evaluation, a risk evaluation system is established in combination with the risk evaluation theory, and correct and scientific methods are applied to objectively evaluate project risks and provide reference for investment decision makers. Theoretical basis and methods. The author believes that there are many kinds of evaluation methods, but after comparison, the multi-factor evaluation method of environmental risk is a relatively simple and easy to use method with comparative reference value.

Sources of Environmental Risks of Industrial Enterprises an example presented on Risk categories: Air Pollution, Water pollution, Solid waste pollution, sound pollution, Radiation pollution and Others (Tab. 2).

A multi-factor analysis and evaluation method for environmental risks of industrial enterprises. This method is generally used for the evaluation of pollutants (dust, objects, gases, waste, wastewater, light pollution, chemicals, etc.) and noise emissions.

Evaluation formula of Risk [10]:

$$
X=a \times M
$$

where, $\mathrm{X}$ - environmentalrisk score;

$\mathrm{a}$ - frequencyof occurrence;

$\mathrm{M}$ - maximum of $\mathrm{b}, \mathrm{c}, \mathrm{d}$ or e indicator;

$\mathrm{b}$ - ratioof the emission value to the legal standard value (or management control);

c-scopeand extent of influence;

d-recoverabilityor sustainability of environmental impact;

e-publicor media attention (sensitivity).

TABLE II. RISK CATEGORIES AND SOURCES

\begin{tabular}{|l|l|l|}
\hline $\begin{array}{c}\text { Serial } \\
\text { number }\end{array}$ & \multicolumn{1}{|c|}{$\begin{array}{c}\text { Risk } \\
\text { category }\end{array}$} & \multicolumn{1}{|c|}{ Main source of risk } \\
\hline 1 & Air Pollution & $\begin{array}{l}\text { Carbon emissions, industrial waste gas, } \\
\text { combustion residues and various dust }\end{array}$ \\
\hline 2 & $\begin{array}{l}\text { Water } \\
\text { pollution }\end{array}$ & Production wastewater and domestic sewage \\
\hline 3 & $\begin{array}{l}\text { Solid waste } \\
\text { pollution }\end{array}$ & $\begin{array}{l}\text { Waste oil, oily sludge, paint waste, heat } \\
\text { treatment waste, surface treatment waste, } \\
\text { etc. }\end{array}$ \\
\hline 4 & $\begin{array}{l}\text { sound } \\
\text { pollution }\end{array}$ & $\begin{array}{l}\text { Production overhaul, mechanical } \\
\text { processing, equipment operation, the whole } \\
\text { process of product production }\end{array}$ \\
\hline 5 & $\begin{array}{l}\text { Radiation } \\
\text { pollution }\end{array}$ & $\begin{array}{l}\text { Radioactive minerals and metals, waste } \\
\text { residues, etc., reflection sources of various } \\
\text { light pollution sources, etc. }\end{array}$ \\
\hline 6 & $\begin{array}{l}\text { Other } \\
\text { pollution }\end{array}$ & $\begin{array}{l}\text { Hazardous chemicals, hazardous production } \\
\text { materials, other dangerous goods }\end{array}$ \\
\hline
\end{tabular}

Maximum value of $\mathrm{M}$. The specific evaluation method is: the five evaluation factors $\mathrm{a}, \mathrm{b}, \mathrm{c}, \mathrm{d}$, and e are based on the frequency of occurrence, the ratio of the emission value to the safety value, the scope and extent of the impact, the recoverability or sustainability of the impact, and the attention of the group. The degree or sensitivity is divided into five levels from high to low and assigned different points.

The higher the level, the higher the score. Select the maximum value among b, c, d, and e, multiply it with a, and the final result is an environmental risk score. The value of the evaluation factor can be set with reference to Tab. 3, or it can be set by the enterprise itself.

After determining the important environmental factors and the priority item level of important environmental factors, the environmental factor score $\mathrm{X}$ value is determined, and then the environmental factor evaluation should be carried out according to the score: $M=5$ or $X=25$, then the risk level is an urgent priority; $X \geq 20$, then The risk level is high, and the risk index is $10 ; X=16$ can be judged as medium risk, and the risk index is 6 ; when $X \leq 15$, it is in the low-risk stage, and the risk index is 2 . Enterprises can make corresponding adjustments according to different risk indexes.

However, the environmental risk assessment index based on this method should pay attention to the following points:

- The environmental factors that have violated or are close to violating the requirements of laws and mandatory standards (such as excessive emissions) are directly determined as important environmental factors;

- It is not illegal in general environmental factors, but environmental factors that are highly concerned or 
mandatory monitored by relevant local government departments should be determined as important environmental factors;

- Substances that the government or the law expressly prohibits the use, restricts the use, or replaces the use within a time limit shall be determined as important environmental factors;

- The use and leakage of hazardous waste and hazardous chemicals should be determined as important environmental factors;

- If the company's most important energy material has the greatest potential for control and saving, it is judged as an important environmental factor;

- Environmental factors (such as fire, leakage of dangerous goods, etc.) that are expected to have serious environmental impacts under abnormal or emergency conditions should be determined as important environmental factors;

- Environmental factors that are of high concern or clearly required by related parties shall be determined as important environmental factors.

TABLE III. MULTI-FACTOR EVALUATION METHOD SCORING STANDARDS

\begin{tabular}{|c|c|c|}
\hline Evaluation factor & Rating description & Score \\
\hline \multirow[t]{5}{*}{ Frequency a } & Continuous occurrence-once a day & 5 \\
\hline & Once a day-once a week & 4 \\
\hline & Once a week-once a month & 3 \\
\hline & Once a month-once a year & 2 \\
\hline & Once more than a year (occasionally) & 1 \\
\hline \multirow{5}{*}{$\begin{array}{l}\text { Emission value and } \\
\text { regulatory standard value } \\
\text { Than b (or management } \\
\text { control) }\end{array}$} & $\geq 100 \%$ (or uncontrolled) & 5 \\
\hline & $80 \%-100 \%$ & 4 \\
\hline & $\begin{array}{l}50 \% \sim 80 \% \text { (may be controlled, but } \\
\text { not thorough) }\end{array}$ & 3 \\
\hline & $30 \% \sim 50 \%$ & 2 \\
\hline & $\begin{array}{l}30 \% \text { or less (or completely under } \\
\text { control) }\end{array}$ & 1 \\
\hline \multirow[t]{5}{*}{$\begin{array}{l}\text { Scope and extent of } \\
\text { influence } \mathrm{c}\end{array}$} & $\begin{array}{l}\text { Severe national and global } \\
\text { destruction }\end{array}$ & 5 \\
\hline & $\begin{array}{l}\text { Serious damage to the province or } \\
\text { city }\end{array}$ & 4 \\
\hline & More severe damage near the town & 3 \\
\hline & Minor impact near the factory & 2 \\
\hline & In-plant influence & 1 \\
\hline \multirow{5}{*}{$\begin{array}{ll}\text { Recoverability } & \text { or } \\
\text { ustainability } & \text { of } \\
\text { environmental impact d }\end{array}$} & $\begin{array}{l}\text { Unrecoverable or recoverable over } \\
\text { one year }\end{array}$ & 5 \\
\hline & Recover within half a year to one year & 4 \\
\hline & $\begin{array}{l}\text { Recover within one week to six } \\
\text { months }\end{array}$ & 3 \\
\hline & Recover within one day to one week & 2 \\
\hline & Recover within one day & 1 \\
\hline \multirow{2}{*}{$\begin{array}{l}\text { Public and media } \\
\text { attention } \mathrm{e}\end{array}$} & International attention & 5 \\
\hline & State pays great attention & 4 \\
\hline
\end{tabular}

\begin{tabular}{|l|l|l|}
\hline \multirow{2}{*}{ Evaluation factor } & \multicolumn{1}{|c|}{ Rating description } & Score \\
\hline \multirow{4}{*}{} & Regional concern & 3 \\
\cline { 2 - 3 } & General attention near the factory & 2 \\
\cline { 2 - 3 } & Not for concern & 1 \\
\hline
\end{tabular}

Problems of the enterprise. For most companies in newly industrialized countries, the pursuit of economic demands exceeds other parts, which is a very realistic problem. At present, the main problems in these countries are:

- The lack of corporate environmental compliance risk functional departments;

- The lack of systematization, the relative independence of various departments within the corporate management system, the lack of effective communication mechanisms, and the lack of functional departments, As a result, the entire enterprise environmental risk management work is neglected;

- The demands of the economy make the current enterprise environmental management systems in these countries be standardized and procedurally inadequate, requiring more principles, less specific procedural control, and poor operability;

- Companies only regard environmental management as a passive behavior under legal enforcement. When economic goals and environmental goals conflict, companies often sacrifice environmental goals to achieve economic goals;

- The corporate leadership does not pay enough attention to environmental protection and self-Poor awareness of prevention;

- Insufficient means. Some seriously polluting enterprises, although aware of the seriousness of the risk of violations, are limited to the existing management, technology and knowledge level, and it is difficult to find effective risk identification, risk prevention and remediation methods and mechanism [11-13].

The government's corporate environmental policies address environmental risk issues.

- Adjusting and optimizing the industrial structure to make the industrial layout more reasonable;

- Increasing the intensity of pollution control investment, which requires a large amount of budget and approval process, therefore, the responsibility of relevant government environmental departments is a requirement;

- 3.Optimize the pollution source structure and other aspects, and use and build a reasonable and effective external supervision mechanism, so as to be able to propose corresponding policy recommendations based on the results of the company's environmental risk assessment [14-18].

From the enterprise level: 
- Establish an enterprise environmental risk emergency response center, and set up an emergency response center in industrial enterprises, especially high-pollution and high-consumption industrial enterprises that are monitored, and establish a platform to integrate environmental protection, public safety, and fire protection. Medical assistance, natural disaster prevention and other resources are integrated and unified deployment is implemented [19-21]. An industrial enterprise should establish four levels of emergency response systems, namely, the emergency response center of the city where it is located, the emergency response center of the county where it is located, the emergency response center of the town or district where it is located, and the emergency sub-center within the enterprise plant area. The four-level response system can be Realize the docking and linkage of emergency response level by level between enterprise-town-countycity [22-23];

- Establish an enterprise environmental risk emergency response system. The internationally accepted emergency response system is the area promulgated by the United Nations Environment Program The emergency response system (APELL), combined with APELL's ideas, establishes an emergency prevention and response system suitable for the enterprise's own characteristics, to minimize the incidence of various dangerous accidents, and minimize the loss in the event of an accident, so as to ensure the stable operation and lasting competitiveness of industrial enterprises. The emergency response system industry enterprise should integrate information collection, transmission, feedback, regional security monitoring, accident and disaster early warning, dispatching command, and a comprehensive management system. It conducts a unified response to the police and handles issues related to public safety, road traffic, fire protection, disaster prevention and mitigation, environmental protection, medical first aid, municipal emergency rescue, and emergencies in industrial enterprises; and coordinates the area according to the corresponding emergency plan [24-27]. Enterprises, in conjunction with professional departments such as public safety, fire protection, disaster prevention, environmental protection, maritime affairs, first aid, etc., deal with various emergencies in a timely and effective manner [28-30];

- Establish a sound environmental risk management system, and manufacturers must manage safety, The leaders and production managers of industrial enterprises must pay attention to safety work, earnestly implement the safety production responsibility system at all levels to enhance independent innovation capabilities, develop low-pollution and high-efficiency alternative processes, and constantly improve their own risk avoidance mechanisms, and pay attention to the enterprise itself The construction of an environmental risk team regularly evaluates related environmental risk projects, and immediately improves and perfects environmental risks [31-32].

\section{CONCLUSION}

This article starts with data related to the industrial development of the BRICS countries, and begins to pay attention to the corporate environmental risks of China, Russia and other BRICS countries. It focuses on a simple and easy-tooperate multi-factor evaluation method for environmental factors. This method has a wide range of adaptability and the problem is that the scientificity needs to be improved. This method does not require high knowledge and ability of the operator, and does not require complex tools for initial statistics. If you conduct a deeper research, you should pay attention to the widespread use of China's power and energy industries. TOPSIS method. The author hopes that relevant industrial enterprises in China can pay more attention to the level of enterprise construction management and pollutant emission control. Ultimately, constitute an effective sustainable development model for industrial enterprises.

\section{Acknowledgments}

The author would like to thank the co-supervisor, wellregarded professor Tatyana Yuryevna Anopchenko. The completion of this article is inseparable from the direction and research field she directed. The author will continue the research of in-depth aspects of corporate environmental management and corporate environmental risks. The aurhor also thanks the scholars and lists their works in the references.

This work was supported by the Russian Foundation for Basic Research: project no. 18-010-00594

\section{References}

[1] H. Xuanda and S. Hucai, "The Basis Of Risk Management-Mathematical Methods", Nanjing: Southeast University Press, 2001, pp. 12-27.

[2] M.M. Hamed and P.B. Brfirmy, "On The Performance Of Computional Methods For The Assessment Of Risk From Ground Watercontamination", Ground Water, 1997, vol. 35(4), pp. 638-646.

[3] E. Mario and S. Giuseppe, "Fuzzy Approach To The Environmental Impact Evaluation”, Ecological Modelling, 2001, vol. 135(1), pp. 131 147.

[4] $\mathrm{Xu}$ Gaoling, "The Economic Loss Measurement Of China' Environmental Damage", Beijing: China Environmental Science Press, 1998, pp. 179-222.

[5] Li Zhaodong and Yan Lu, "Environmental audit of production enterprises based on energy quality flow analysis", Auditing and Economic Research, 2010, vol. 2010(1), pp. 24-28

[6] China Statistical Yearbook, 2019. Retrieved from: http://www.stats.gov.cn/tjsj/ndsj/2019/indexch.htm

[7] China Environmental Statistics Annual Report, 2015. Retrieved from https://data.cnki.net/yearbook/Single/N2017050140

[8] BRICS Joint Statistical Publications 2010-2018. Retrieved from: http://www.statssa.gov.za/wp-content/uploads/2018/11/BRICS-JSP2018.pdf

[9] Wu Mengya, "Research on Environmental Risk Assessment of Coal and Electricity Enterprises North China Electric Power University (Beijing)", 2019

[10] T.Y. Anopchenko, A.D. Murzin, E.A. Kandrashina, I.V. Kosyakova and O.E. Surnina, "Environmental Risk To Health Of The Population", International Journal of Environmental and Science Education, 2016, vol. 11(14), pp. 7091-7115.

[11] Wu Yifan, Tu Qinxiao, Wang Yingang, etc. "Research Progress In Environmental Health Risk Assessment", Urban Construction, 2013, vol. 2013(7). 
[12] Chen Yun and Huang Yi, "Environmental risks and control mechanisms in the renewal of industrial areas: Taking Shanghai as an example" Shanghai Urban Planning, 2020, vol. 2020(04), pp. 98-105.

[13] Hou Zhiguo, "Environmental Risk Assessment Of Chemical Enterprises And Emergency Plan For Environmental Emergencies", Modern Industrial Economy and Information Technology, 2020, vol. 10(03), pp. 120-121.

[14] Zhong Wei, Hu Yanjun, Ning Yan and Zhang Guanglin, "Environmental Risk Identification, Evaluation And Risk Prevention And Control Of Iron And Steel Enterprises", Light Industry Science and Technology, 2019, vol. 35(10), pp. 116-117+154.

[15] Shi Jikai, Shao Chaofeng and Ju Meiting, "Research On The Environmental Risk Assessment Index System Of Petrochemical Enterprises", Journal of Safety and Environment, 2015, vol. 15(02), pp. 324-330.

[16] Shi Zheqi, "Research on Environmental Risk Assessment of Petrochemical Enterprises Based on TOPSIS-Analytic Hierarchy Process", Tianjin Polytechnic University, 2019.

[17] Xie Kun, "Research on the Theory and Method of Enterprise Environmental Risk and Value Management", Nanjing University of Aeronautics and Astronautics, 2014.

[18] Chen Yu, "Research on Environmental Risk Assessment Method and Risk Management of Chemical Park Planning", Dalian University of Technology, 2013.

[19] Xiao Xu and Zhou Zhifang, "Research on Enterprise Environmental Risk Management and Environmental Liability Assessment Framework", Audit and Economic Research, 2012, vol. 27(02), pp. 33-40.

[20] W. Wang and Ch.Wang, "Chinese enterprises' environmental protection compliance risk prevention mechanism and countermeasures", Ecological Economy, 2008, vol. 2008(09), pp. 56-58+67.

[21] Ge Yonghui and He Hongmei, "Research on Environmental Risk Prevention and Control Management of Chemical Enterprises", Guangdong Chemical Industry, 2018, vol. 45(02), pp. 144-145. Management. Nanjing University of Aeronautics and Astronautics, 2014.
[22] Yu. Chen, "Research on Environmental Risk Assessment Method and Risk Management of Chemical Park Planning", Dalian University of Technology, 2013.

[23] Xiao Xu and Zhou Zhifang, "Research on Enterprise Environmental Risk Management and Environmental Liability Assessment Framework", Audit and Economic Research, 2012, vol. 27(02), pp. 33-40.

[24] Wang Wenzhong and Wang Chunhui, "Environmental Protection Compliance Risk Prevention Mechanism And Countermeasures Of Chinese Enterprises”, Ecological Economy, 2008, vol. 2008(09), pp. 56$58+67$.

[25] Ge Yonghui and He Hongmei, "Research on Environmental Risk Prevention and Control Management of Chemical Enterprises", Guangdong Chemical Industry, 2018, vol. 45(02), pp. 144-145.

[26] Zeng Guangming and Zhong Zhenglin, "Uncertainty in Environmental Risk Assessment”, China Environmental Science, 1998, vol. 1998(3), pp. 252-255.

[27] Zhang Zheng and Li Yinnian, "Case Analysis Of Environmental Risk Assessment Of Petrochemical Projects", Environmental Science Research, 1999, vol. 1999(2), pp. 32-35.

[28] S. Edward, "Introduction to engineering and the environment", McGrawHill, 2001, pp. 593-599.

[29] T. Yamaguchi and K. Wakasa, "Oil Pool Fire Experiment. In: Fire Salty Science-Proceedings of the First International Symposium”, Japan, 1981, pp. 911-918.

[30] Jia Qian, Huang Lei, Yuan Zengwei, et al. "Research On The Evaluation And Grading Method Of Environmental Risk In Petrochemical Enterprises", Environmental Science Journal, 2014, vol. 30(7), pp. 15101517.

[31] Du Xichen, "Research on Environmental Risk Assessment Methods of Chemical Industry", Lanzhou: Lanzhou University, 2008, pp. 41-47.

[32] A. Helland, "Dealing With Uncertainty And Pursuing Superior Technology Options In Risk Mangement-The Inherency Risk Analysis”, Journal of Hazardous Materials, 2014, vol. 164(2-3), pp. 95-100. 